\title{
The role of structural change in European regional productivity growth
}

\author{
Eoin O'Leary $^{l}$ and Don J. Webber ${ }^{2}$ \\ ${ }^{1}$ Department of Economics, University College, Cork, Ireland \\ ${ }^{2}$ Department of Accounting, Economics and Finance, University of the West of \\ England, Bristol, UK
}

\begin{abstract}
Recent literature suggests that inter-sectoral structural change has a negligible impact on aggregate productivity growth. Through the application of dynamic shift-share methods, this paper presents an empirical re-examination of this perspective using data for 181 European regions from 1980 to 2007. The results suggest that the effect of the inter-sectoral component is far from negligible and is substantially stronger for those regions towards the higher deciles of the distribution. Moreover, its effects appear to be particularly growth enhancing when the region is either 'high and improving' or 'low and deteriorating.' These results rehabilitate the importance of structural change for growth and convergence.
\end{abstract}

Keywords: Regional Productivity; Shift-Share; Structural Change; Growth;

Convergence

JEL Classifications: R11; O47

Acknowledgments: The authors are grateful for helpful comments from Tony Flegg, and seminar participants at the Regional Science Association International (British and Irish Section) Annual Conferences in Stratford on Avon, 2005, Jersey, 2006, and Cardiff, 2011. Thanks to Jon Stenning, Cambridge Econometrics, for helpful discussions around and provision of the data. All errors remain the authors' responsibility.

Address for correspondence: Prof. Don Webber, Department of Accounting, Economics and Finance, University of the West of England, Bristol, BS16 1QY, UK 


\section{Introduction}

Early theoretical contributions on the effects of structural change on growth and convergence expected it to be positive. The beneficial effects on growth come through a reallocation of surplus labour from agriculture to industry and services (Lewis, 1954) and have been referred to by Temple (2001) as the growth bonus. These shifts from the primary to the secondary and tertiary sectors may cause convergence, assuming poor regions have relatively more labour in low-productivity sectors such as agriculture (Abramovitz, 1986). However, in principle, the movement of labour between sectors in search of higher wages may not be confined to poor regions. Rich regions may also grow faster and diverge from other regions through labour reallocation generated between and within sectors. Shifts could occur between low productivity sectors such as textiles and clothing and high-productivity sectors such as electronics, owing for example to increasing returns from technological progress in the latter.

It is an empirical question as to whether, and the extent to which, structural change has been important for growth and convergence/divergence, and whether this is country- and/or region-specific. The main purpose of this paper is to measure the effects of structural change between 15 sectors, including 7 manufacturing and 6 market services sectors, on the growth and convergence/divergence performance of 181 EU regions between 1980 and 2007.

There is an emerging consensus in the literature that the effect of intra-sectoral structural change on aggregate productivity growth and convergence is dominant and that any similar effects of inter-sectoral structural change are negligible. Empirical evidence in support of this is particularly strong in Esteban (2000), Ezcurra et al. 
(2005), Villaverde and Maza (2008) and Le Gallo and Kamarianakis (2011). However, there are exceptions, as Paci and Pigliaru (1997) for Italy, O'Leary (2003a, b) for Ireland, Carluer and Gaulier (2005) for France, and Gil et al. (2002) for the EU find that inter-sectoral structural change is stronger in poorer regions and has a convergent effect.

This paper builds on the work of O'Leary $(2003 a, b)$ and shows that, while structural change, measured as the inter-sectoral contribution, has a smaller growth effect, it becomes progressively more important for the upper deciles of the distribution and is especially important for regions that are 'high and improving' and 'low and deteriorating.'

Policies to stimulate either regional growth or convergence through structural change must be founded, at least in part, on empirical evidence. It is important to know whether, and to what extent, policies that, either by design or through indirect effects, reallocate employment from relatively low to relatively high productivity sectors, have an effect on growth. Moreover, if it does have an effect, will it contribute to convergence or divergence? If poor regions benefit more, then national and EU policies targeted at facilitating structural change may promote the longstanding policy objective of balanced development. However, if rich regions gain more from structural change then the policy debate may need to pay attention to a hitherto overlooked source of divergence.

The next section outlines the debate about convergence and structural change. Sections 3 and 4 describe the data and specify the methodology to be used. Section 5 provides a discussion of the results and Section 6 draws conclusions and policy implications. 


\section{Regional convergence and structural change}

Among EU regions, Gardiner et al. (2004) have shown that regional convergence has been remarkably slow and that the persistence of regional productivity disparities is a key issue for researchers and policy makers. This paper investigates one factor that has effectively been disregarded in terms of its importance for understanding productivity disparities: inter-sectoral structural change. Structural change is a process involving the re-allocation of labour from relatively low to relatively high productivity sectors, thus boosting aggregate national or regional productivity growth. Lewis (1954) hypothesized that increased growth could be attributable to structural change through surplus labour in agriculture being re-allocated to other industries and services. In the convergence debate, Abramovitz suggests that structural change might have a convergent effect:

If countries at relatively low levels of industrialization contain large numbers of redundant workers in farming and petty trade, as is normally the case, there is also an opportunity for productivity growth by improving the allocation of labour (1986: 387).

Thus convergence is the outcome when poor regions with relatively more labour in low-productivity sectors, such as agriculture, exhibit faster productivity growth as a result of reallocating labour.

However, it is too restrictive to assume that structural change necessarily results in convergence. Rich regions may also benefit as labour is re-allocated from industry to services or, indeed, within sectors. This could occur if, in the context of 
increasing international competition, particular sectors in regions benefit more than others from localized increasing returns from technology spillovers (Martin and Sunley, 1998) or agglomeration effects (Krugman, 1991). In a world characterized by endogenous growth or new economic geography models, it is plausible to expect that the 'petty trades' referred to by Abramovitz (1986) could be present in rich regions in relatively low productivity manufacturing or service industries. Hence, structural change might lead to regional divergence if rich regions grow faster as a result of labour re-allocation from relatively low to relatively high productivity sectors.

Structural change is neglected in the neoclassical approach to convergence. Paci and Pigliari (1997) show that, in the neoclassical framework, there is no room for structural change since marginal productivity is assumed to be equal across sectors (see also Gil et al., 2002). Although the standard conditional $\beta$ convergence method includes the initial agricultural employment share as an independent variable, the purpose is not to estimate the effects of structural change, but instead to control for the effect of aggregate shocks on regional productivity growth (see, for example, Button and Pentecost, 1995, and Hoffer and Worgotter, 1997).

Paci and Pigliaru (1997) extended this standard method, by controlling for the sectoral reallocation effect. They argued that aggregate convergence among Italian regions was largely due to this effect, which is calculated using the shift-share method. Cuadrado-Roura et al. (1999) showed that the overall convergence of Spanish regions between 1955 and 1995 was not due to convergence among sectors, and instead argued that convergence was attributable to the homogenization of regional productive structures. 
In a study of Irish regions, O'Leary $(2003 a, b)$ used the shift-share method with the $\sigma$ convergence measure and found that structural change from the primary sector to have had a convergent effect. The approach used in this paper is an extension of this method to 15 sectors and $181 \mathrm{EU}$ regions. It involves decomposing aggregate productivity growth for each region between time periods (years) $t$ and $t+1$ into three components, as follows:

Intra-sectoral productivity growth ratio in region $j=\frac{\sum_{1}^{N}\left(P_{i, j, t+1} S_{i, j, t}\right)}{\sum_{1}^{N}\left(P_{i, j, t} S_{i, j, t}\right)}$

where $i$ and $j$ represent sectors and regions respectively, $P$ is sectoral labour productivity defined as regional gross value added (GVA) per work-hour, $S$ is the sectoral employment share of each region, based on the total number of work-hours, and $N$ is the number of sectors. This intra-sectoral growth measure captures annual aggregate growth due to sectoral productivity growth, and the growth ratio in equation (1) may be used to calculate annual growth rates.

The next component is the inter-sectoral structural growth ratio. This captures the effect of structural change through inter-sectoral labour re-allocation as follows:

Inter-sectoral structural growth ratio in region $j=\frac{\sum_{1}^{N}\left(P_{i, j, t} S_{i, j, t+1}\right)}{\sum_{1}^{N}\left(P_{i, j, t} S_{i, j, t}\right)}$ 
The final component is the residual, which is usually small and is the interaction between the intra-sectoral and inter-sectoral components, such that:

Residual productivity growth ratio in region $j=\frac{\sum_{1}^{N}\left(P_{i, j, t+1}-P_{i, j, t}\right)\left(S_{i, j, t+1}-S_{i, j, t}\right)}{\sum_{1}^{N}\left(P_{i, j, t} S_{i, j, t}\right)}$

It should be clarified that structural change is captured exclusively in intersectoral component (2). However, structural change also contributes to the residual component, which is an interaction term. ${ }^{1}$ For completeness, the overall contribution of structural change is also calculated as the difference between aggregate productivity growth and intra-sectoral productivity growth which, in effect, refers to the combination of both inter-sectoral and residual components, and represents an upperbound on its contribution.

While the shift-share technique has limitations, especially in the area of forecasting (Stevens and Moore, 1980), it is in widespread use in the analysis of labour re-allocation and growth in the regional literature (see, for example, Le Gallo and Kamarianakis, 2011; Oosterhaven and Broersma, 2007; Ezcurra et al., 2005). The proposed measures avoid the use of initial year's weights of $S_{i, j}$, which have been widely used and can lead to an under-estimation of the contribution of structural change over time (Broadberry, 1998). This problem is overcome by taking previous year values, so that the proposed method can be characterized as dynamic shift-share.

Esteban (2000) uses a similar shift-share method and finds that most of the observed inter-regional variance in aggregate productivity among EU regions is attributable to regional productivity differentials. This suggests that inter-sectoral 
structural change has had a negligible effect on growth. However, this finding may partly be due to Esteban's study being confined to a very small number of years (1986 and 1989).

Ezcurra et al. (2005) adopted a similar method to Esteban (2000) and overcame the problem of a severely limited time period by investigating EU regions over the 1977-99 period using Cambridge Econometrics data. Their regional differential component is defined as the productivity gap between each region and the EU average, while the structural component refers to the difference between the region's industry mix and the EU average. ${ }^{2}$ After first regressing each component on the aggregate regional productivity gap relative to the EU average over time, Ezcurra et al. (2005) showed that the regional component had the greatest explanatory power, with a minor role for the structural component. They then conducted a variance decomposition of regional productivity and concluded that the strongest impact came from the regional component. This led to their suggestion that structural change was unimportant and that a one-sector growth model is more relevant for analysing regional disparities. More recently, Le Gallo and Kamarianakis (2011) employed a similar methodology, with similar results.

While the present paper employs a similar methodology, there are some noteworthy differences. In particular, Ezcurra et al. (2005) and Le Gallo and Kamarianakis (2011) computed the regional and structural components at a point in time with reference to the EU average. This amounts to attributing the difference between aggregate regional growth and the EU average to each region's industry mix and differential components relative to that average. However, Equations (1) and (2) above show that these components may be computed based on the historical evolution 
of each region over time, and not with reference to an arbitrary average. In addition, this paper also provides more detailed econometric testing of the effects of structural change on growth.

To develop the argument, the paper continues by estimating the effect of intrasectoral productivity growth and structural change, as measured above, on overall productivity growth. The first step is to investigate the relationship between aggregate productivity growth and aggregate intra-sectoral productivity growth, as follows:

$$
\frac{\left(P_{i, a g g, t+1}-P_{i, a g g, t}\right)}{P_{i, a g g, t}}=\alpha+\beta\left[\frac{\sum_{1}^{N}\left(P_{i, j, t+1} S_{i, j, t}\right)-\sum_{1}^{N}\left(P_{i, j, t} S_{i, j, t}\right)}{\sum_{1}^{N}\left(P_{i, j, t} S_{i, j, t}\right)}\right]+\varepsilon_{i, j, t}
$$

where $P_{i, a g g}$ is aggregate regional productivity, defined as total regional GVA per work-hour. It is hypothesized that $\beta$ is positive and close to unity, which would corroborate the results of Ezcurra et al. (2005).

The next stage is to analyse the relationship between aggregate productivity growth and the different measures of structural change. These are productivity growth equations focusing on inter-sectoral (Equation (5)), the residual component (Equation (6)) and the inter-sectoral combined with the residual component (Equation (7)), such that:

$$
\frac{\left(P_{i, a g g, t+1}-P_{i, a g g, t}\right)}{P_{i, a g g, t}}=\alpha+\beta\left[\frac{\sum_{1}^{N}\left(P_{i, j, t} S_{i, j, t+1}\right)-\sum_{1}^{N}\left(P_{i, j, t} S_{i, j, t}\right)}{\sum_{1}^{N}\left(P_{i, j, t} S_{i, j, t}\right)}\right]+\varepsilon_{i, j, t}
$$




$$
\begin{aligned}
& \frac{\left(P_{i, a g g, t+1}-P_{i, a g g, t}\right)}{P_{i, a g g, t}}=\alpha+\beta\left[\frac{\sum_{1}^{N}\left(P_{i, j, t+1} P_{i, j, t}\right)\left(S_{i, j, t+1} S_{i, j, t}\right)}{\sum_{1}^{N}\left(P_{i, j, t} S_{i, j, t}\right)}\right]+\varepsilon_{i, j, t} \\
& \frac{\left(P_{i, \text { agg }, t+1}-P_{i, a g g, t}\right)}{P_{i, a g g, t}}=\alpha+\beta\left[\frac{\left(P_{i, a g g, t+1} P_{i, a g g, t}\right)}{P_{i, a g g, t}}-\left[\frac{\sum_{1}^{N}\left(P_{i, j, t+1} S_{i, j, t}\right)-\sum_{1}^{N}\left(P_{i, j, t} S_{i, j, t}\right)}{\sum_{1}^{N}\left(P_{i, j, t} S_{i, j, t}\right)}\right]\right]+\varepsilon_{i, j, t}
\end{aligned}
$$

Again in line with the findings of Ezcurra et al. (2005), it is hypothesized that the values of $\beta$, especially in Equations (5) and (7), which represent the lower and upper bound, respectively, of the contribution of structural change, are close to zero.

In estimating these equations, it is normally assumed that the effects are identical across the whole distribution. A key contribution of this paper is to move away from this restrictive assumption and to use quantile regression techniques. This would involve estimating the effects of both intra- and inter-sectoral change on productivity levels, while controlling for the region's productivity relative to average EU regional productivity (denoted by $P_{E U, a g g, t}$ ), to capture convergence towards the mean, such that:

$$
P_{i, a g g, t}=\alpha+\beta_{1}\left(\frac{P_{i, a g g, t}}{P_{E U, a g g, t}}\right)+\beta_{2}\left(\frac{\sum_{1}^{N}\left(P_{i, j, t+1} S_{i, j, t}\right)-\sum_{1}^{N}\left(P_{i, j, t} S_{i, j, t}\right)}{\sum_{1}^{N}\left(P_{i, j, t} S_{i, j, t}\right)}\right)+\beta_{3}\left(\frac{\sum_{1}^{N}\left(P_{i, j, t} S_{i, j, t+1}\right)-\sum_{1}^{N}\left(P_{i, j, t} S_{i, j, t}\right)}{\sum_{1}^{N}\left(P_{i, j, t} S_{i, j, t}\right)}\right)+\varepsilon_{i, j, t}(8)
$$




\section{Data description}

The empirical analyses use data corresponding to 181 EU regions for the period 19802007 that has been extracted from the Cambridge Econometrics (2009) database. ${ }^{3}$ The advantages of this data source are that it provides sectoral gross value added (GVA) at constant prices and purchasing power parities and labour input for a large number of NUTS 2 regions between 1980 and 2007. Labour input is measured as total hours worked, computed as employment multiplied by average weekly hours worked. Gardner et al. (2004) argued for the superiority of this measure of labour input. A further benefit of the dataset is that a high degree of sectoral disaggregation is provided, with 15 sectors being available. ${ }^{4} \mathrm{GVA}$ is in constant $€ 2000$ basic prices and purchasing power standards. Cambridge Econometrics employs national sector specific price deflators, which assumes that, for any sector, price movements are the same across all regions in a country. The Cambridge Econometrics (2009) dataset draws data from REGIO, which is the official source of EU regional data (Eurostat, $2004)^{5}$

Table 1 summarizes the number of NUTS 2 regions investigated for each of 13 EU countries, all of which were members of the original EU 15. While NUTS 2 administrative regions are not ideal measures of functional regions (Magrini, 1999), they are frequently used. For Belgium, two regions are excluded owing to irregularities with the sectoral data. For Germany, only the 30 former West German regions are included owing to their data being available from 1980. Groningen in the Netherlands and North-Eastern Scotland in the UK are excluded because of the influence of North-Sea oil (see also Neven and Guoyette, 1995). In addition, 
Flevoland in the Netherlands is excluded as it only came into existence in 1986. All 13 regions of Greece are excluded, owing to irregularities with the sectoral data, while Luxembourg is excluded for obvious reasons. With these exclusions, we are left with a balanced set of 181 regions across $13 \mathrm{EU}$ countries for 27 years.

\{Insert Table 1 about here $\}$

\section{Econometric approach}

To identify stability and consistency in the results, three separate time-series-crosssection estimators were applied. The models were estimated initially using fixed effects with robust variances. This approach allows for the control of omitted variables that differ between regions but are constant over time. Employing fixed effects would be appropriate if the regional effects remained constant over time. However, this may be an unnecessarily restrictive assumption, which may not hold for some regions; this is because the effects of some omitted variables may be constant over time, yet vary across regions, while others may be fixed across regions but vary over time. Accordingly, we re-estimate the models using generalized least squares (GLS) random effects, which produces a matrix-weighted average of the between and within region results. Here Hausman's test indicated throughout that models assuming fixed effects models were preferable to those assuming random effects; nevertheless, the results of both types of model are presented to illustrate the stability of coefficients across estimators with different underlying assumptions. 
Nevertheless, the application of the above regression approaches implicitly assumes that the disturbance term is identically and independently distributed, yet this may not be the case if the errors are correlated over time. As a result, the model was re-estimated by using a time-series-cross-section estimator with a first-order autoregressive disturbance term (see Baltagi and $\mathrm{Wu}, 1999$ ).

The above three regression approaches, which are extensions of those used by Ezcurra et al. (2005), were applied to data over the entire time period and across the whole sample. However, there is the possibility that intra- and inter-sectoral changes have different effects on labour productivity, depending on whether the region is above or below the sample average, and whether the region is converging or diverging from that sample average. To investigate these propositions further, we re-estimated the above models for these four categories.

Application of these regression methods is based on the implicit assumption that the effects of explanatory variables on productivity do not vary with the relative values of regions. This assumption is relaxed through the application of quantile regressions, which permits an exploration into the differing effects that intra- and inter-sectoral structural change may have on labour productivity over time, depending on where regions lie within the productivity distribution.

\section{Results}

This section initially presents estimates of the time-series-cross-section estimations of the effects of intra- and inter-sectoral change on labour productivity growth. 


\section{i) Aggregate productivity growth and the intra-sector measure}

To identify the importance of intra-sectoral change on aggregate productivity growth we estimate Equation (4). The results presented in Panel A of Table 2 indicate that intra-sectoral change has a statistically significant and enhancing effect on aggregate productivity growth. Because of omitted variables, the consistently high $R^{2}$ values may overstate the importance of intra-sectoral change per se; nevertheless, this result illustrates the importance of intra-sectoral change for productivity growth at the NUTS 2 regional level and corroborates the findings of Ezcurra et al. (2005).

\{Insert Table 2 about here $\}$

\section{ii) Aggregate productivity growth and the inter-sector measure}

To identify the importance of inter-sectoral change on aggregate productivity growth we estimate Equation (5). Here the results presented in Panel B of Table 2 suggest that inter-sectoral change is not a major driving force behind productivity growth, a finding that is similar to that of Ezcurra et al. (2005).

iii) Aggregate productivity growth and the residual component

For completeness, the above methods are applied to the residual measure. Panel $\mathrm{C}$ of Table 2 presents the results for Equation (6). Two important points are worth emphasising. First, the statistical significance of the residual measure varies 
depending on the estimator used, suggesting a small degree of instability, but more strikingly the $R^{2}$ values are incredibly small, suggesting that the explanatory power of the residual measure on productivity growth is small. This is to be expected as the residual component itself is usually very small.

iv) Aggregate productivity growth and the combined inter-sectoral and residual components

Application of the econometric methods to the estimation of Equation (7) yields the results presented in Panel D of Table 2. These results suggest that the combined intersectoral and residual components have a statistically significant and negative association with productivity growth, although the explanatory power is invariably extremely low.

v) Quantile regression

Taken together, the results presented above confirm the findings of authors such as Ezcurra et al. (2005), by suggesting that a region's rate of productivity growth is mostly explained by intra-sectoral change and that inter-sectoral change and the residual have relatively minor contributory effects. One potential disadvantage of the econometric approaches applied above, which are conventional in the literature, is the implicit underlying assumption that the effects are identical across the whole distribution of regions. This implicit assumption is neither theoretically justifiable nor 
in line with the work of Lewis (1954) and Abramovitz (1986), who focused on the benefits of labour reallocation within relatively less developed areas.

In order to identify whether this implicit assumption is justifiable, we investigate the effects of intra-sectoral and structural change on labour productivity growth through the application of quantile regressions. Given the findings in panels C and D of Table 2, which reveal that the effects of the residual component on growth are weak, we chose to focus solely on the inter-sectoral component. Application of Equation (8), which takes into consideration the relative position of the region in the distribution at time $t$, as well as the separate intra- and inter-sectoral change effects, yields the results presented in Table 3. These new results cast doubt on the stability and validity of our earlier findings for each and every decile in the distribution. The $\beta_{1}$ coefficient, which captures the initial position of a region within the distribution, suggests that a region above (below) the mean will grow slightly faster (slower) than the mean; note that they are not statistically significantly different from unity for the $4^{\text {th }}$ and $5^{\text {th }}$ deciles. These results suggest that there is divergence in the sample after account has been taken of the effects of measures of structural change. Also notable are that the models have greater explanatory power as one ascends the distribution. ${ }^{6}$ For convenience, the structural change coefficients are graphed in Figure 1, which emphasises the non-linear effects, especially of inter-sectoral change, on productivity.

\{Insert Table 3 and Figure 1 about here

Figure 1 reveals that the effects of intra- and inter-sectoral change on a region's productivity depend on where it is in the distribution. Figure 1 shows that the 
effect of intra-sectoral change on a region's productivity is invariably strongly positive and is relatively similar across the distribution. However, although the effect of intersectoral change on productivity is always less than that for the intra-sectoral component, it is far from being negligible. Indeed, the inter-sectoral effect depends on where the region is located in the distribution, with it being substantially stronger for those regions towards the top of the distribution. This finding contradicts the proposition that poorer regions are likely to benefit most from structural change, as a result of having large pools of relatively low-productivity agricultural workers (see, for example, Temple (2001) and O'Leary (2003a, b). By conducting the analysis at a greater level of sectoral disaggregation, this paper has uncovered a significant source of benefit to richer regions from structural change.

\section{vi) Further analysis}

Academics and policy makers who pay attention to this literature tend to be interested in whether a region is above or below an average and whether its performance is on an upward or downward relative trajectory. Accordingly, it may be practical and valuable to investigate the effects of structural changes on productivity relative to the sample mean for four groups of regions based on a categorisation of productivity performance over the entire time period: i) those regions that are relatively rich and becoming more so, ii) those regions that are relatively rich but are deteriorating, iii) those regions that are relatively poor but improving, and (iv) those regions that are relatively poor and are deteriorating further (see Appendix 2 for list of regions in each category and Appendix 3 for set of results). 
The effect of intra-sectoral change is relatively consistent across the four groups. However, it is also noticeable that the effect of inter-sectoral change on productivity growth differs depending on how a region is performing. Its effect appears to be particularly growth enhancing if the region is 'low and deteriorating' and 'high and improving', as emphasised in Figure 2. Conversely, the effect is much smaller if the region is 'low and improving' and 'high and deteriorating'. This suggests that structural change may be a strong contributory factor in these diverging regions and further reinforces the view that structural change should feature in policy recommendations, as these regions cope with negative and positive shocks.

\section{\{Insert Figure 2 about here $\}$}

\section{Conclusions}

This paper has presented a set of empirical tests of the effects of structural change on EU regional productivity growth. The empirical approach saw the application of a dynamic shift-share approach to a 15 sector measure of GVA per work-hour for 181 EU regions from 1980 to 2007 . The paper is distinctly different from others, such as Ezcurra (2005), principally because of its more detailed econometric testing of the effects of structural change on growth and the fact that its computation of the contribution of structural change to the change in productivity is based on the historical evolution of each region over time.

The main findings are that: 
(i) intra-sectoral change was positively related to regional productivity growth, with inter-sectoral change having much smaller effects;

(ii) for deciles of the distribution, the effect of the inter-sectoral component is far from negligible, and is substantially stronger for those regions towards the top of the distribution;

(iii) the effect of inter-sectoral change appears to be particularly growth enhancing if the region is 'low and deteriorating' and 'high and improving'.

These results rehabilitate the importance of structural change for growth and convergence. They cast doubt on the current view that the intra-sectoral contribution is the dominant and perhaps only source of productivity growth, and that inter-sectoral structural change has a negligible impact (Ezcurra et al., 2005; Villaverde and Maza, 2008; Le Gallo and Kamarianakis, 2011).

This paper has important policy implications. First, the finding that structural change can make a significant contribution to productivity growth in richer regions suggests that policies should be targeted at facilitating it in these regions through education, training and infrastructure measures directed at improving labour mobility, both within and across sectors and regions. Such measures may have contradictory effects on regional convergence/divergence. For poor regions that are falling behind average growth, adopting such policies could contribute to convergence to the average. However, for rich regions that are moving ahead of average growth, adopting similar policies will have divergent effects. 
The finding that inter-sectoral structural change is important for growth of regional productivity is the most important contribution of this paper. This hypothesis could be tested for data sets with larger numbers of sectors, regions and countries and for longer time periods. It may also be investigated for neighbouring region effects, in that regions may benefit more in terms of productivity growth attributable to labour re-allocation from regions that are geographically proximate. The results of Le Gallo and Kamarianakis (2011), which point to the importance of geographical clustering, suggest that this might be a fruitful extension of this line on inquiry. Indeed, this could involve the application of the methods proposed by Mayer and Lopez (2008) to introduce spatial dependence in a shift-share model. 


\section{References}

Abramovitz, M. (1986). Catching Up, Forging Ahead and Falling Behind, Journal of Economic History. 46(2): pp 385-406.

Arellano, M. and Bond, S. (1991) Some Tests of Specification for Panel Data: Monte Carlo Evidence and an Application to Employment, Review of Economic Studies 58(2), pp. 277-297

Baltagi, B. and P. Wu. 1999. Unequally spaced panel data regressions with AR(1) disturbances, Econometric Theory 15, pp 814-823 u/1 case?

Broadberry, S.N. (1998). How Did the United States and Germany Overtake Britain? A Sectoral Analysis of Comparative Productivity Levels, 1870-1990. The Journal of Economic History, 58(2): pp 375-407

Button K. J. and Pentecost E. J. (1995). Testing for Convergence of the EU Regional Economies. Economic Inquiry. XXXIII: pp 664-671

Cambridge Econometrics (2009). European Regional Data: 1980-2007. Cambridge Econometrics, UK. [Available on request - see http://www.camecon.co.uk]

Carluer F and G Gaulier (2005). The Impact of Convergence in the Industrial Mix on Regional Comparative Growth: Empirical Evidence from the French Case. Annals of Regional Science. 39: pp 85-105.

Cuadrado-Roura J.R., Garcia Greciano B and Raymond J.L. (1999). Regional Convergence in Productivity and Productive Structure: the Spanish Case. International Regional Science Review 22: pp 35-53.

Esteban J (2000). Regional Convergence in Europe and the Industry Mix: A Shift-Share Analysis. Regional Science and Urban Economics. 30(3): pp 353-364.

Eurostat (2004). European Regional Statistics: REGIO, Eurostat, Luxembourg, July $4^{\text {th }}$.

Ezcurra R, Gil C, Pascual P and Rapun M (2005). Regional Inequality in the European Union: Does Industry Mix Matter? Regional Studies. 39(6): pp 679-698.

Gardiner B, Martin R and Tyler P (2004). Competitiveness, Productivity and Economic Growth across the European Regions. Regional Studies. 38(9): pp 1045-1068.

Gil Caneleta C., P. Pascual Arzoz and M. Rapun Garate (2002). Structural Change, Infrastructure and Convergence in the Regions of the European Union. European Urban and Regional Studies. 9(2): pp 115-135.

Hoffer H and Worgotter A (1997). Regional Per Capita Income Convergence in Austria. Regional Studies. 31(1): pp 1-12.

Krugman P (1991). Increasing Returns and Economic Geography. Journal of Political Economy, 99: pp 483-99.

Le Gallo J and Kamarianakis Y. (2011). The Evolution of Regional Productivity Disparities in the European Union from 1975 to 2002: A Combination of Shift-Share and Spatial Econometrics. Regional Studies, 45(1): pp 123-139. 
Lewis A. (1954). Development with Unlimited Supplies of Labour, The Manchester School XXII: pp 139-191, May.

Magrini S. (1999). The evolution of income disparities among the regions of the European Union. Regional Science and Urban Economics, 29: pp257-281.

Martin R. L. and Sunley P. J. (1998) Slow convergence? The new endogenous growth theory and regional development, Economic Geography 74, pp 201-227.

Mayer, M. and A.J. Lopez (2008). Spatial Shift Share Analysis versus Spatial Filtering: An Application to Spanish Employment Data. Empirical Economics, 34: pp123-142.

Neven D and Guoyette C (1995). Regional Convergence in the European Community. Journal of Common Market Studies. 33 (1): pp 47-65.

O’Leary E (2003a). Aggregate and Sectoral Convergence Among Irish Regions: The Role of Structural Change: 1960-96. International Regional Science Review. 26 (4): pp 483-501.

O’Leary E (2003b). Sources of Regional Divergence in the Celtic Tiger: Policy Responses. Journal of the Statistical and Social Inquiry Society of Ireland. XXXII: pp 1-32.

Oosterhaven J and L. Broersma (2007). Sector Structure and Cluster Economies: A Decomposition of Regional Labour Productivity. Regional Studies, 41(5): pp 639-659.

Paci R and Pigliaru F (1997). Structural Change and Convergence: An Italian Regional Perspective. Structural Change and Economic Dynamics. 8: pp 297-318.

Quah D. (1996). Empirics for Economic Growth and Convergence. European Economic Review. 40 (6): pp 1353-76.

Stevens B.H. and Moore C.L. (1980). A Critical Review of the Literature on Shift-Share as a Forecasting Technique. Journal of Regional Science, 20(4): 419-437.

Temple J. (2001). Structural Change and Europe's Golden Age, Centre for Economic Policy Research, Discussion Paper No. 2861, June.

Villaverde J. and A. Maza (2008). Regional Convergence in the European Regions, 1980-2003: A Sectoral and Spatial Approach. Applied Economics. (40): 1299-1313. 
Figure 1: Quantile regression estimates

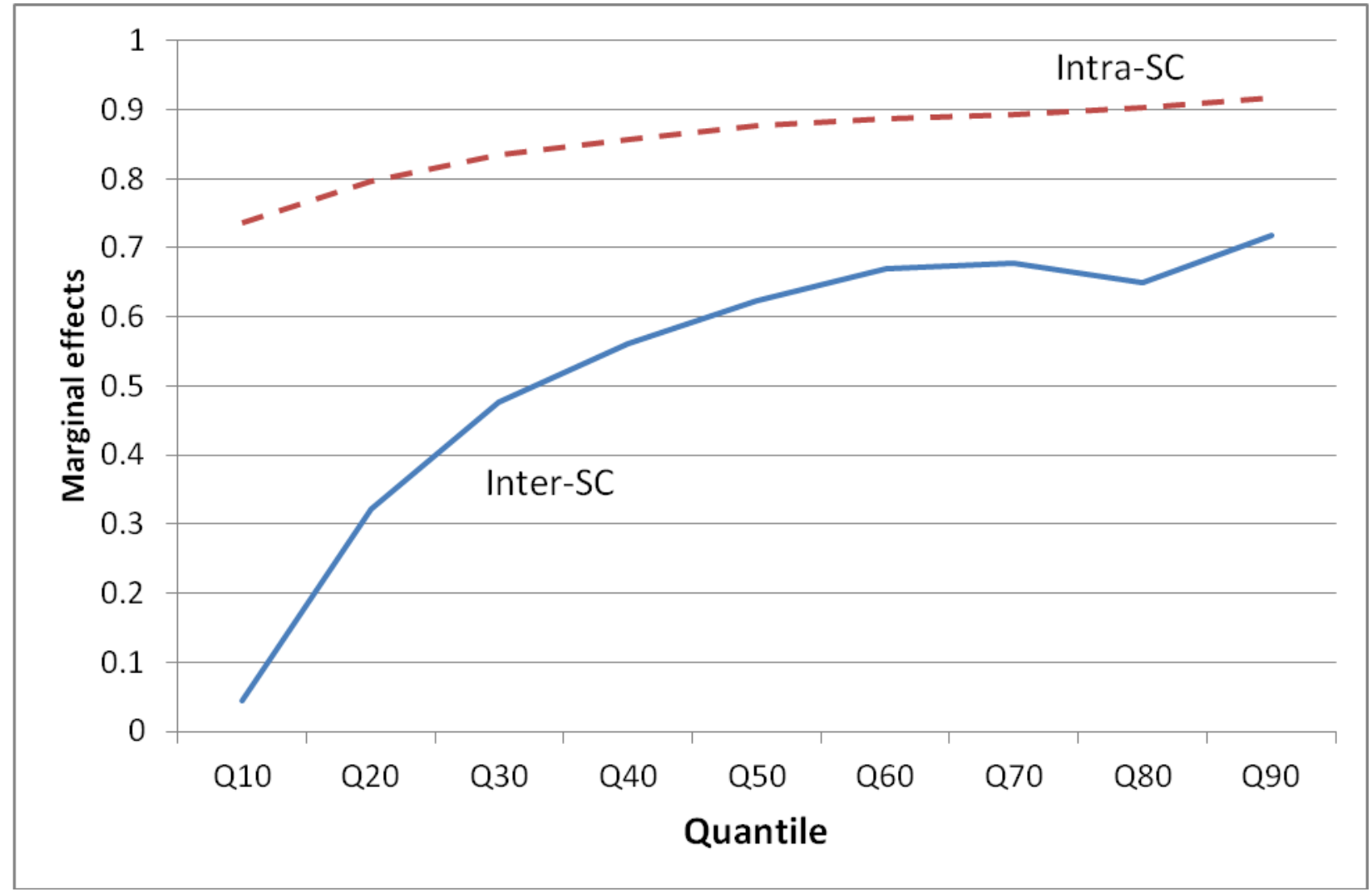


Figure 2: Marginal effects by category, based on random effects estimator

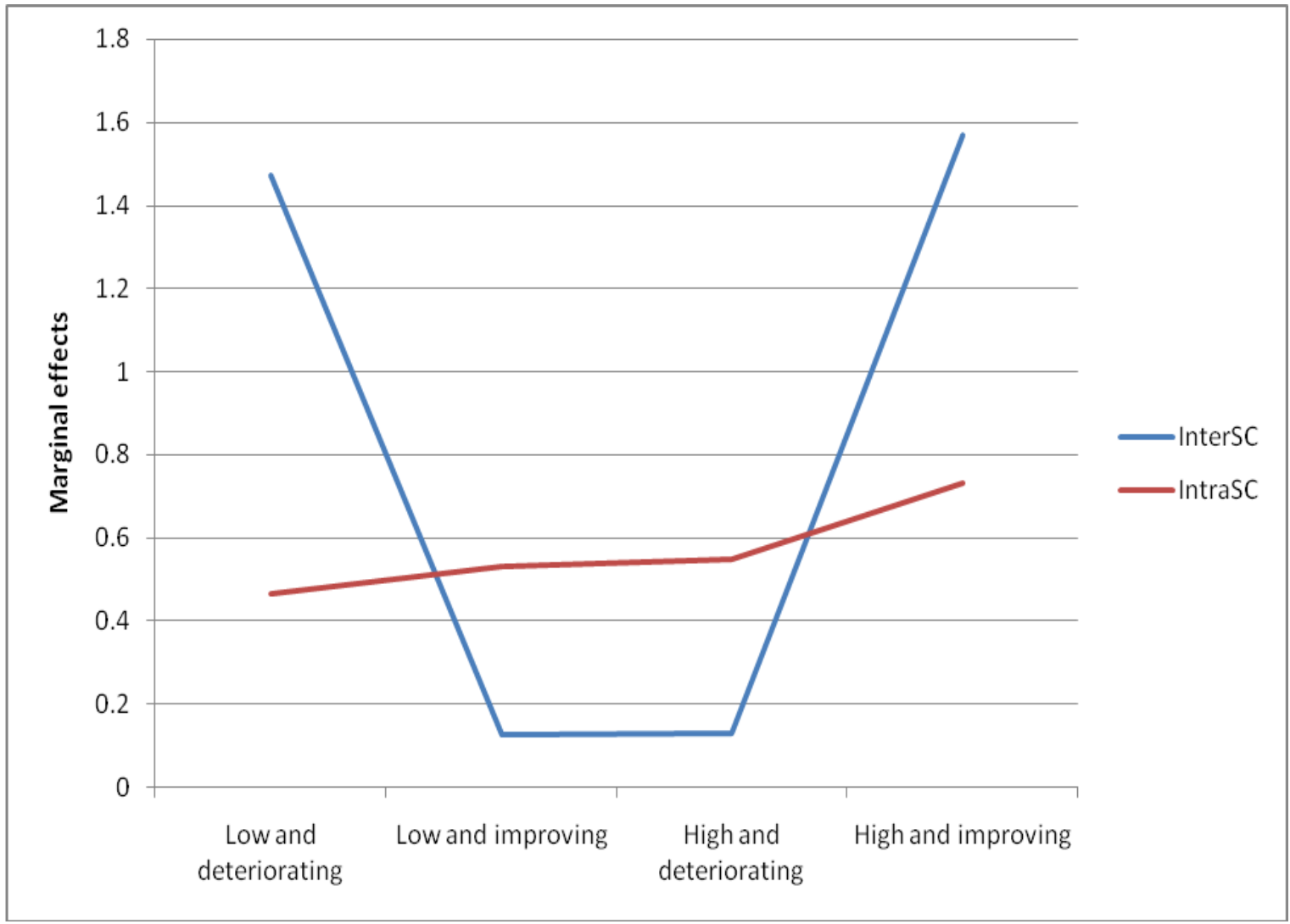


Table 1: Number of EU NUTS 2 regions

\begin{tabular}{|c|c|}
\hline Country & NUTS 2 Regions \\
\hline Belgium $^{1}$ & 9 \\
\hline Denmark & 5 \\
\hline Germany $^{2}$ & 30 \\
\hline Spain & 19 \\
\hline France & 22 \\
\hline Italy & 21 \\
\hline The Netherlands ${ }^{3}$ & 10 \\
\hline Austria & 9 \\
\hline Portugal $^{4}$ & 5 \\
\hline Finland & 5 \\
\hline Sweden & 8 \\
\hline Ireland & 2 \\
\hline $\mathrm{UK}^{5}$ & 36 \\
\hline Total $^{6}$ & 181 \\
\hline
\end{tabular}

Source: Cambridge Econometrics (2009).

Notes 1: $\quad$ Excluding the region West Brabant and Brabant Wallon.

2: $\quad$ Includes only the former West German regions.

3. Groningen and Flevoland excluded.

4: $\quad$ Excluding Azores and Madeira.

5: $\quad$ North-East Scotland excluded

6: $\quad$ All 13 regions of Greece excluded. 
Table 2: Shift-share regression results

\begin{tabular}{|c|c|c|c|c|c|c|}
\hline & $\alpha$ & $\begin{array}{l}\text { Intra- } \\
\text { structural } \\
\text { change }\end{array}$ & $\begin{array}{l}\text { Inter- } \\
\text { structural } \\
\text { change }\end{array}$ & $\begin{array}{c}\text { Residual } \\
\text { component }\end{array}$ & $\begin{array}{c}\text { Inter- structural } \\
\text { change and } \\
\text { Residual } \\
\text { Combined } \\
\end{array}$ & $\begin{array}{c}R^{2} \mathrm{~s} \\
\text { [Within] } \\
\text { \{Between } \\
\text { Overall } \\
\end{array}$ \\
\hline \multicolumn{7}{|c|}{ Panel A: Equation (4): Intra-sectoral component of productivity growth } \\
\hline $\begin{array}{l}\text { Fixed effects with } \\
\text { robust variance }\end{array}$ & $\begin{array}{c}0.004 \\
(0.000)^{* * *}\end{array}$ & $\begin{array}{c}0.918 \\
(0.026)^{* * *}\end{array}$ & - & - & - & $\begin{array}{c}{[0.941]} \\
\{0.925\} \\
0.939\end{array}$ \\
\hline Random effects GLS & $\begin{array}{c}0.004 \\
(0.000)^{* * *}\end{array}$ & $\begin{array}{c}0.918 \\
(0.003)^{* * *}\end{array}$ & - & - & - & $\begin{array}{c}{[0.941]} \\
\{0.925\} \\
0.939\end{array}$ \\
\hline $\begin{array}{l}\text { Random effects GLS } \\
\text { regression with } \\
\text { AR(1) disturbances }\end{array}$ & $\begin{array}{c}0.004 \\
(0.000)^{* * *}\end{array}$ & $\begin{array}{c}0.917 \\
(0.003)^{* * *}\end{array}$ & - & - & - & $\begin{array}{c}{[0.944]} \\
\{0.790\} \\
0.939 \\
\end{array}$ \\
\hline \multicolumn{7}{|c|}{ Panel B: Equation (5): Inter-sectoral component of productivity growth } \\
\hline $\begin{array}{l}\text { Fixed effects with } \\
\text { robust variance }\end{array}$ & $\begin{array}{c}0.019 \\
(0.000)^{* * *}\end{array}$ & 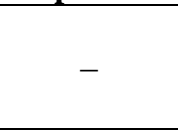 & $\begin{array}{c}0.001 \\
(0.026)\end{array}$ & - & - & $\begin{array}{c}{[0.000]} \\
\{0.108\} \\
0.000 \\
\end{array}$ \\
\hline Random effects GLS & $\begin{array}{c}0.019 \\
(0.001)^{* * *}\end{array}$ & - & $\begin{array}{c}0.014 \\
(0.019)\end{array}$ & - & - & $\begin{array}{c}{[0.000]} \\
\{0.108\} \\
0.000\end{array}$ \\
\hline $\begin{array}{l}\text { Random effects GLS } \\
\text { regression with } \\
\text { AR(1) disturbances }\end{array}$ & $\begin{array}{c}0.019 \\
(0.001)^{* * *}\end{array}$ & - & $\begin{array}{c}0.013 \\
(0.019)\end{array}$ & - & - & $\begin{array}{c}{[0.000]} \\
\{0.108\} \\
0.000\end{array}$ \\
\hline \multicolumn{7}{|c|}{ Panel C: Equation (6): Growth and the residual component of productivity growth } \\
\hline $\begin{array}{l}\text { Fixed effects with } \\
\text { robust variance }\end{array}$ & $\begin{array}{c}0.019 \\
(0.000)^{* * *}\end{array}$ & - & - & $\begin{array}{l}-0.049 \\
(0.029)\end{array}$ & - & $\begin{array}{c}{[0.001]} \\
\{0.104\} \\
0.002 \\
\end{array}$ \\
\hline Random effects GLS & $\begin{array}{c}0.019 \\
(0.001)^{* * *}\end{array}$ & - & - & $\begin{array}{c}-0.064 \\
(0.021)^{* * *}\end{array}$ & - & $\begin{array}{c}{[0.001]} \\
\{0.104\} \\
0.002\end{array}$ \\
\hline $\begin{array}{l}\text { Random effects GLS } \\
\text { regression with } \\
\text { AR(1) disturbances }\end{array}$ & $\begin{array}{c}0.019 \\
(0.001)^{* * *}\end{array}$ & - & - & $\begin{array}{c}-0.064 \\
(0.021)^{* * *}\end{array}$ & - & $\begin{array}{c}{[0.001]} \\
\{0.104\} \\
0.002 \\
\end{array}$ \\
\hline \multicolumn{7}{|c|}{ Panel D: Equation (7): Inter-sectoral and residual components combined of productivity growth } \\
\hline $\begin{array}{l}\text { Fixed effects with } \\
\text { robust variance }\end{array}$ & $\begin{array}{c}0.021 \\
(0.001)^{* * *}\end{array}$ & - & - & - & $\begin{array}{c}-0.328 \\
(0.192)^{*}\end{array}$ & $\begin{array}{c}{[0.008]} \\
\{0.000\} \\
0.007\end{array}$ \\
\hline Random effects GLS & $\begin{array}{c}0.020 \\
(0.001)^{* * *}\end{array}$ & - & - & - & $\begin{array}{c}-0.294 \\
(0.052)^{* * *}\end{array}$ & $\begin{array}{c}{[0.008]} \\
\{0.000\} \\
0.007 \\
\end{array}$ \\
\hline $\begin{array}{l}\text { Random effects GLS } \\
\text { regression with } \\
\text { AR(1) disturbances }\end{array}$ & $\begin{array}{c}0.020 \\
(0.001)^{* * *}\end{array}$ & - & - & - & $\begin{array}{c}-0.299 \\
(0.052)^{* * *}\end{array}$ & $\begin{array}{c}{[0.007]} \\
\{0.000\} \\
0.007 \\
\end{array}$ \\
\hline
\end{tabular}

Notes: standard errors in parentheses. $* * *, * *$ and $*$ signify statistical significance at the $1 \%, 5 \%$ and $10 \%$ levels, respectively. 
Table 3: Estimation of Equation (8): Quantile regressions

\begin{tabular}{|c|c|c|c|c|c|c|}
\hline Quantile & $\alpha$ & $\begin{array}{l}\left(\beta_{1}\right) \text { Initial } \\
\text { position }\end{array}$ & $\left(\beta_{2}\right)$ Intra-SC & $\left(\beta_{3}\right)$ Inter-SC & $R^{2}$ & $\begin{array}{c}\text { Test } \\
H_{o}: \beta_{I}=1\end{array}$ \\
\hline Q90 & $\begin{array}{l}-0.012 \\
(0.001)^{* * * *}\end{array}$ & $\begin{array}{l}1.005 \\
(0.002) * * *\end{array}$ & $\begin{array}{l}0.917 \\
(0.009) * * *\end{array}$ & $\begin{array}{l}0.718 \\
(0.057) * * *\end{array}$ & 0.760 & $12.07 * * *$ \\
\hline Q80 & $\begin{array}{l}-0.015 \\
(0.001)^{* * *}\end{array}$ & $\begin{array}{l}1.005 \\
(0.002)^{* * *}\end{array}$ & $\begin{array}{l}0.902 \\
(0.009)^{* * *}\end{array}$ & $\begin{array}{l}0.650 \\
(0.044) * * *\end{array}$ & 0.721 & $23.73 * * *$ \\
\hline Q70 & $\begin{array}{l}-0.017 \\
(0.001) * * *\end{array}$ & $\begin{array}{l}1.005 \\
(0.001)^{* * *}\end{array}$ & $\begin{array}{l}0.893 \\
(0.007)^{* * * *}\end{array}$ & $\begin{array}{l}0.678 \\
(0.048) * * *\end{array}$ & 0.696 & $34.68 * * *$ \\
\hline Q60 & $\begin{array}{l}-0.016 \\
(0.001)^{* * *}\end{array}$ & $\begin{array}{l}1.003 \\
(0.001)^{* * *}\end{array}$ & $\begin{array}{l}0.886 \\
(0.008) * * *\end{array}$ & $\begin{array}{l}0.669 \\
(0.059) * * *\end{array}$ & 0.674 & $10.80 * * *$ \\
\hline Q50 & $\begin{array}{l}-0.016 \\
(0.001)^{* * * *}\end{array}$ & $\begin{array}{l}1.001 \\
(0.001)^{* * *}\end{array}$ & $\begin{array}{l}0.876 \\
(0.010) * * *\end{array}$ & $\begin{array}{l}0.623 \\
(0.073) * * *\end{array}$ & 0.650 & 1.35 \\
\hline Q40 & $\begin{array}{l}-0.015 \\
(0.001) * * *\end{array}$ & $\begin{array}{l}0.999 \\
(0.001) * * *\end{array}$ & $\begin{array}{l}0.857 \\
(0.012)^{* * *}\end{array}$ & $\begin{array}{l}0.561 \\
(0.081)^{* * *}\end{array}$ & 0.624 & 0.40 \\
\hline Q30 & $\begin{array}{l}-0.013 \\
(0.001) * * *\end{array}$ & $\begin{array}{l}0.996 \\
(0.001)^{* * *}\end{array}$ & $\begin{array}{l}0.835 \\
(0.014)^{* * *}\end{array}$ & $\begin{array}{l}0.477 \\
(0.100) * * * \\
\end{array}$ & 0.591 & $7.92 * * *$ \\
\hline Q20 & $\begin{array}{l}-0.012 \\
(0.002)^{* * *}\end{array}$ & $\begin{array}{l}0.993 \\
(0.002)^{* * *}\end{array}$ & $\begin{array}{l}0.796 \\
(0.014) * * *\end{array}$ & $\begin{array}{l}0.321 \\
(0.145)^{* *}\end{array}$ & 0.545 & $19.66 * * *$ \\
\hline Q10 & $\begin{array}{l}-0.012 \\
(0.003) * * *\end{array}$ & $\begin{array}{l}0.986 \\
(0.003) * * *\end{array}$ & $\begin{array}{l}0.736 \\
(0.022) * * *\end{array}$ & $\begin{array}{l}0.045 \\
(0.142)\end{array}$ & 0.470 & $19.85 * * *$ \\
\hline
\end{tabular}

Note: These coefficients can be interpreted as marginal effects. Estimates are based on 1000 bootstraps. 


\section{Appendix 1: Table A1: 15 Sectoral classification (NACE Rev 1)}

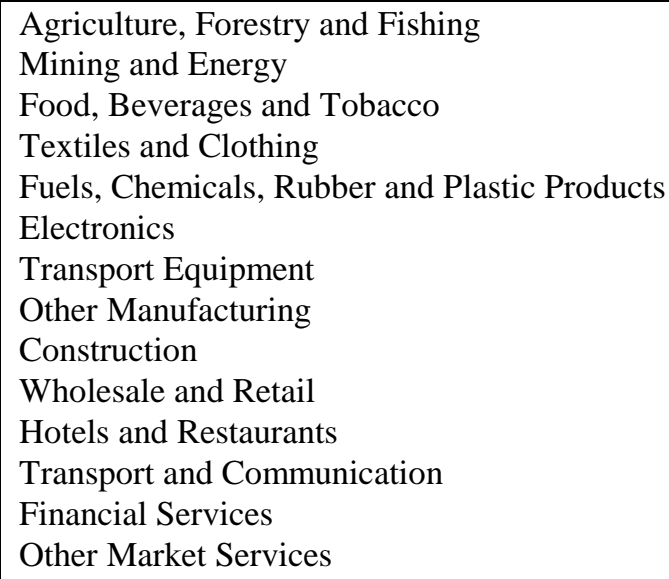

\section{Appendix 2: Group memberships}

Low and Deteriorating $(N=16)$ :

Syddanmark (dk03), Midtjylland (dk04), Cantabria (es13), Castilla y León (es41), Castilla-la Mancha (es42), Extremadura (es43), Andalucia (es61), Región de Murcia (es62), Åland (fi2), Puglia (itf4), Småland med öarna (se21), Merseyside (ukd5), South Yorkshire (uke3), Devon (ukk4), West Wales and The Valleys (ukl1) and South Western Scotland (ukm3).

Low and improving $(N=81)$ :

Burgenland (at11), Niederösterreich (at12), Kärnten (at21), Steiermark (at22), Freiburg (de13), Niederbayern (de22), Oberpfalz (de23), Oberfranken (de24), Unterfranken (de26), Hannover (de92), Lüneburg (de93), Weser-Ems (de94), Münster (dea3), Detmold (dea4), Koblenz (deb1), Trier (deb2), Saarland (dec), Sjælland (dk02), Nordjylland (dk05), Galicia (es11), Principado de Asturias (es12), La Rioja (es23), Aragón (es24), Comunidad Valenciana (es52), Ciudad Autónoma de Ceuta (es63), Ciudad Autónoma de Melilla (es64), Canarias (es7), Itä-Suomi (fi13), LänsiSuomi (fi19), Pohjois-Suomi (fi1a), Basse-Normandie (fr25), Pays de la Loire (fr51), Bretagne (fr52), Poitou-Charentes (fr53), Limousin (fr63), Auvergne (fr72), Corse (fr83), Border, Midlands and Western (ie01), Abruzzo (itf1), Molise (itf2), Campania (itf3), Basilicata (itf5), Calabria (itf6), Sardegna (itg2), Norte (pt11), Algarve (pt15), Centro (pt16), Lisboa (pt17), Alentejo (pt18), Östra Mellansverige (se12), Sydsverige (se22), Västsverige (se23), Tees Valley and Durham (ukc1), Northumberland, Tyne and Wear (ukc2), Cumbria (ukd1), Greater Manchester (ukd3), Lancashire (ukd4), East Yorkshire and Northern Lincolnshire (uke1), North Yorkshire (uke2), West Yorkshire (uke4), Derbyshire and Nottinghamshire (ukf1), Leicestershire, Rutland and Northants (ukf2), Lincolnshire (ukf3), Herefordshire, Worcestershire and Warks (ukg1), Shropshire and Staffordshire (ukg2), West Midlands (ukg3), East Anglia (ukh1), Bedfordshire and Hertfordshire (ukh2), Essex (ukh3), Outer London (uki2), Berkshire, Bucks and Oxfordshire (ukj1), Surrey, East and West Sussex (ukj2), Hampshire and Isle of Wight (ukj3), Kent (ukj4), Gloucestershire, Wiltshire and Bristol/Bath area (ukk1), Dorset and Somerset (ukk2), Cornwall and Isles of Scilly 
(ukk3), East Wales (ukl2), Eastern Scotland (ukm2) and Highlands and Islands (ukm6) and Northern Ireland (ukn).

High and deteriorating $(N=66)$ :

Oberösterreich (at31), Salzburg (at32), Tirol (at33), Vorarlberg (at34), Région de Bruxelles-Capitale/Brussels Hoofdstedelijk Gewest (be1), Prov. Antwerpen (be21), Prov. Oost-Vlaanderen (be23), Prov. West-Vlaanderen (be25), Prov. Hainaut (be32), Prov. Liège (be33), Prov. Luxembourg (be34), Prov. Namur (be35), Stuttgart (de11), Karlsruhe (de12), Tübingen (de14), Oberbayern (de21), Mittelfranken (de25),

Schwaben (de27), Bremen (de5), Darmstadt (de71), Gießen (de72), Kassel (de73), Braunschweig (de91), Düsseldorf (dea1), Köln (dea2), Arnsberg (dea5), RheinhessenPfalz (deb3), Schleswig-Holstein (def), Pais Vasco (es21), Comunidad Foral de Navarra (es22), Comunidad de Madrid (es3), Cataluña (es51), Illes Balears (es53), Etelä-Suomi (fi18), Picardie (fr22), Bourgogne (fr26), Lorraine (fr41), Alsace (fr42), Franche-Comté (fr43), Midi-Pyrénées (fr62), Languedoc-Roussillon (fr81), Southern and Eastern (ie02), Piemonte (itc1), Valle d'Aosta/Vallée d'Aoste (itc2), Liguria (itc3), Lombardia (itc4), Provincia Autonoma Bolzano-Bozen (itd1), Provincia Autonoma Trento (itd2), Veneto (itd3), Friuli-Venezia Giulia (itd4), Emilia-Romagna (itd5), Toscana (ite1), Umbria (ite2), Marche (ite3), Lazio (ite4), Sicilia (itg1), Friesland (nl12), Drenthe (nl13), Gelderland (nl22), Zeeland (nl34), Stockholm (se11), Norra Mellansverige (se31), Mellersta Norrland (se32), Övre Norrland (se33), Cheshire (ukd2) and Inner London (uki1).

High and improving $(N=18)$ :

Wien (at13), Prov. Limburg (be22), Hamburg (de6), Hovedstaden (dk01), Île de France (fr1), Champagne-Ardenne (fr21), Haute-Normandie (fr23), Centre (fr24), Nord - Pas-de-Calais (fr3), Aquitaine (fr61), Rhône-Alpes (fr71), Provence-AlpesCôte d'Azur (fr82), Overijssel (nl21), Utrecht (nl31), Noord-Holland (nl32), ZuidHolland (nl33), Noord-Brabant (n141) and Limburg (n142).

Appendix 2: Categories, random effects estimator

\begin{tabular}{|l|l|l|l|l|c|}
\hline Method & \multicolumn{1}{|c|}{$\alpha$} & \multicolumn{1}{|c|}{$\begin{array}{c}\text { Initial } \\
\text { position }\end{array}$} & \multicolumn{1}{|c|}{ Intra-SC } & \multicolumn{1}{|c|}{$\begin{array}{c}R^{2} \mathrm{~s} \\
\text { Inter-SC }\end{array}$} & $\begin{array}{c}\text { [Within] } \\
\text { \{Between } \\
\text { Overall }\end{array}$ \\
\hline High and improving $(n=18)$ & $\begin{array}{l}0.737 \\
(0.025)^{* * *}\end{array}$ & $\begin{array}{l}1.81 \mathrm{e}-05 \\
(9.95 \mathrm{e}-07)^{* * * *}\end{array}$ & $\begin{array}{l}0.733 \\
(0.109)^{* * *}\end{array}$ & $\begin{array}{l}1.570 \\
(0.473)^{* * * *}\end{array}$ & $\begin{array}{c}{[0.283]} \\
\{0.991\} \\
0.438\end{array}$ \\
\hline High and deteriorating $(n=66)$ & $\begin{array}{l}0.619 \\
(0.014)^{* * *}\end{array}$ & $\begin{array}{l}2.14 \mathrm{e}-05 \\
(6.12 \mathrm{e}-07)^{* * *}\end{array}$ & $\begin{array}{l}0.549 \\
(0.055)^{* * *}\end{array}$ & $\begin{array}{l}0.129 \\
(0.056)^{* *}\end{array}$ & $\begin{array}{c}{[0.219]} \\
\{0.986\} \\
0.413\end{array}$ \\
\hline Low and improving $(n=81)$ & $\begin{array}{l}0.418 \\
(0.009)^{* * *}\end{array}$ & $\begin{array}{l}2.56 \mathrm{e}-05 \\
(5.00 \mathrm{e}-07)^{* * *}\end{array}$ & $\begin{array}{l}0.529 \\
(0.041)^{* * *}\end{array}$ & $\begin{array}{l}0.126 \\
(0.077)\end{array}$ & $\begin{array}{c}{[0.337]} \\
\{0.997\} \\
0.555\end{array}$ \\
\hline Low and deteriorating $(n=16)$ & $\begin{array}{l}0.603 \\
(0.026)^{* * *}\end{array}$ & $\begin{array}{l}1.4 \mathrm{e}-05 \\
(1.44 \mathrm{e}-06)^{* * *}\end{array}$ & $\begin{array}{l}0.464 \\
(0.099)^{* * *}\end{array}$ & $\begin{array}{l}1.474 \\
(0.381)^{* * * *}\end{array}$ & $\begin{array}{c}{[0.043]} \\
\{0.849\} \\
0.193\end{array}$ \\
\hline
\end{tabular}

Notes: standard errors in parentheses. $* * *, * *$ and $*$ signify statistical significance at the $1 \%, 5 \%$ and $10 \%$ levels respectively. 


\section{Endnotes}

This is the difference between $\left(\Sigma \mathrm{P}_{\mathrm{i}, \mathrm{j}, t+1} \mathrm{~S}_{\mathrm{i}, \mathrm{j}, \mathrm{t}+1}\right) /\left(\Sigma \mathrm{P}_{\mathrm{i}, \mathrm{j}, \mathrm{t}} \mathrm{S}_{\mathrm{i}, \mathrm{j}, \mathrm{t}}\right)$ and Equation (1).

2 Using this paper's notation, Ezcurra et al. (2005) define the regional differential as $\left(\Sigma P_{i, j} S_{i,}\right)-\left(\Sigma P_{i} S_{i}\right)$ and the industry mix as $\left(\Sigma P_{i,} S_{i, j}\right)-\left(\Sigma P_{i} S_{i}\right)$. An interaction or allocative component is also analysed, equal to $\left(\Sigma\left(P_{i, j}-P_{i}\right)\left(S_{i, j}-S_{i}\right)\right) . P_{i}$ and $S_{i}$ refer, respectively, to average EU sectoral productivity levels and sectoral employment shares for a given year while $j$ refers to regions.

3 Ezcurra et al. (2005) used the same source from 1977 to 1999.

4 See Table A1 in Appendix for the sectoral definitions.

5 REGIO is incomplete, with full series not available for all EU countries, especially at the detailed sectoral level.

6 The effects of structural change on regions towards the bottom of the distribution may be smaller because of other factors that have not been accounted for in our modelling process; these factors may correspond to the communication infrastructure (roads, broadband, etc.), the quality of the labour force, outmigration of skilled labour, etc. 